\title{
New Product Launch For Eagle Brand: Marketing Management Case Study - A And B
}

Amy MacMillan, Kalamazoo College, USA

\begin{abstract}
This two-part case study provides a realistic, thought-provoking, and mildly entertaining venture into the world of new product launches. Structured questions are posed at the end of each case, with suspense and information building from Case $A$ to $B$.

Case A asks whether and how to champion a new product launch internally, while Case B additionally explores how to sell the idea externally with a marketing plan. Both case studies are intended for undergraduate marketing or management classes.

Ambitious, young Abbie MacFeldon joined a consumer packaged goods company as Brand Manager of its biggest brand, Eagle shoe care. She identifies the need for a new product, a line extension within her brand-a mature brand in need of new life. Her manager applauds her initiative but says this idea was tried before and failed. The reader learns information about the market, brand, consumer, and company through historical and current data, employee bios, and meetings between Abbie and her colleagues. The reader is asked whether Abbie may have a big idea after all, and if so, how it should be marketed. To make these decisions, readers evaluate external factors (market, competition, consumer, trends) and internal factors (strategic fit, brand image, cost, feasibility, resources). Furthermore, the case provokes the reader to think about how a brand manager can overcome initial rejection, build and motivate a team, and convince top management. The case explores the role of company culture, including age, gender, and tradition, and how the young female protagonist can address these.
\end{abstract}

Keywords: New Product Launch; Brand Manager; Team Building; Marketing or Management Case Study

This case is realistic, but fictitious. Any resemblance to real persons, data, or events is coincidental.

\section{INTRODUCTION}

"The Eagle brand is trustworthy and dependable. Everyone knows they make the best shoe polish in the world. After my dad served in World War II, he never used another brand, and neither will I."

Samuel Rogers, retired sales executive

"Eagle? It's a bird, right?"

Katie Fong, college student

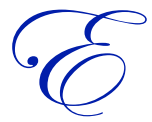

agle, Inc. (EI), an old established firm headquartered in Springfield, Indiana, is the world's largest manufacturer of products that shine, clean, and protect shoes of all materials and styles. The company also produces toilet bowl cleaners, insecticides, and soaps under different brands. In the United States, the Eagle brand is the number one player in shoe care, highly recognized and trusted among older adults, men in particular. Eagle enjoys strong national distribution and a large shelf presence across a range of 184 product line items in grocery, drug, mass merchandise, and specialty shoe store outlets. However, the market is slowly declining and is not well developed among younger people and women of all ages. Retailers are beginning to discontinue 
items for which sales have started to lag. The Eagle brand remains highly profitable, with a long history of success under its belt, and the company prides itself as the world's foremost expert in shoe care.

\section{HISTORY}

Eagle shoe polish was invented in 1879 by Elliot Gould, a Canadian salesman seeking to keep a brilliant shine on his shoes as he sold his wares. He named the polish after the bird that symbolized the country of his American-born wife, Lucinda, with whom he had eight children. In 1889, the family moved to Lucinda's hometown, Springfield, Indiana, where Gould relocated and expanded his business, The Eagle Shoe Polish Company. The polish developed a following among men in business and the military who appreciated its ability to produce a glowing "spit shine."

During World War II, the brand captured the attention of military personnel globally, who were impressed with the Americans' boots. After the war, sales grew briskly, fueled by exports and eventually the creation of subsidiaries around the world. In 1963, the company, now publically traded, changed its name to Eagle Shoe Care, Inc., reflecting expansion into a wide range of products beyond polish, including protectors, cleaners, and shoe laces. Over the next three decades, as non-leather shoe materials became increasingly popular, the company added products to clean and restore sport shoes, suede, and nu-buck.

In the early 1980s, the company acquired a mid-sized toilet bowl cleaner brand, Penguin, followed by two smaller acquisitions in insecticides and industrial soaps, under the Robin and Cardinal brands, respectively. In 1986, the company was renamed Eagle, Inc., signaling its breadth beyond shoe care.

\section{PRESENT DAY}

Today, Eagle shoe care products are sold in 103 countries under the familiar, majestic, spread-winged bird logo. Products vary widely by country, but the most popular product remains the $11 / 8$ ounce round tin of black polish, containing a hard wax, often referred to as 'wax polish' or 'paste polish.'

The top-selling Eagle brand shoe care stock-keeping units (SKUs) are shown in Table 1.

Table 1. Top-Selling Eagle Brand SKUs: Percent of Total Brand Unit Volume

\begin{tabular}{c|l|r}
\hline$\# 1$ & $11 / 8$ oz. Round Tin of Wax Shoe Polish, black & $21 \%$ \\
\hline$\# 2$ & $11 / 8$ oz. Round Tin of Wax Shoe Polish, brown & $11 \%$ \\
\hline$\# 3$ & 4 fl. oz. Bottle of Liquid Shoe Polish, black & $6 \%$ \\
\hline$\# 4$ & 4 fl. oz. Bottle of Liquid Shoe Polish, white & $6 \%$ \\
\hline$\# 5$ & $31 / 2$ oz. Instant Shoe Shine Sponge, clear & $5 \%$ \\
\hline$\# 6$ & $11 / 8$ oz. Round Tin of Wax Shoe Polish, cordovan & $3 \%$ \\
\hline$\# 7$ & 4 fl. oz. Bottle of Liquid Shoe Polish, brown & $3 \%$ \\
\hline$\# 9$ & 16 oz. Protector Spray & $2 \%$ \\
\hline$\# 10$ & 5 fl. oz. Bottle of Sneaker Cleaner with scrubber top & $2 \%$ \\
\hline & $11 / 8$ oz. Round Tin of Wax Shoe Polish, tan & \\
\hline
\end{tabular}

Globally, the Eagle brand's share of the shoe care market is highest in the USA, with a commanding $53 \%$ unit share and $59 \%$ dollar share. In unit share dominance, the USA is followed by Canada (52\%), the U.K (49\%), and Australia (48\%). The highest per capita consumption is in Kenya and South Africa, at seven units per adult, per year. Competition in the USA comes from ShineMaster, a budget brand sold in grocery, drug, and mass merchandise stores, and Dermott, sold exclusively in specialty shoe and shoe repair stores. Unit and dollar shares of the USA shoe care market in 2015 are graphed in Figures 1 and 2. 
Figure 1. Share of USA Shoe Care Market (Units)

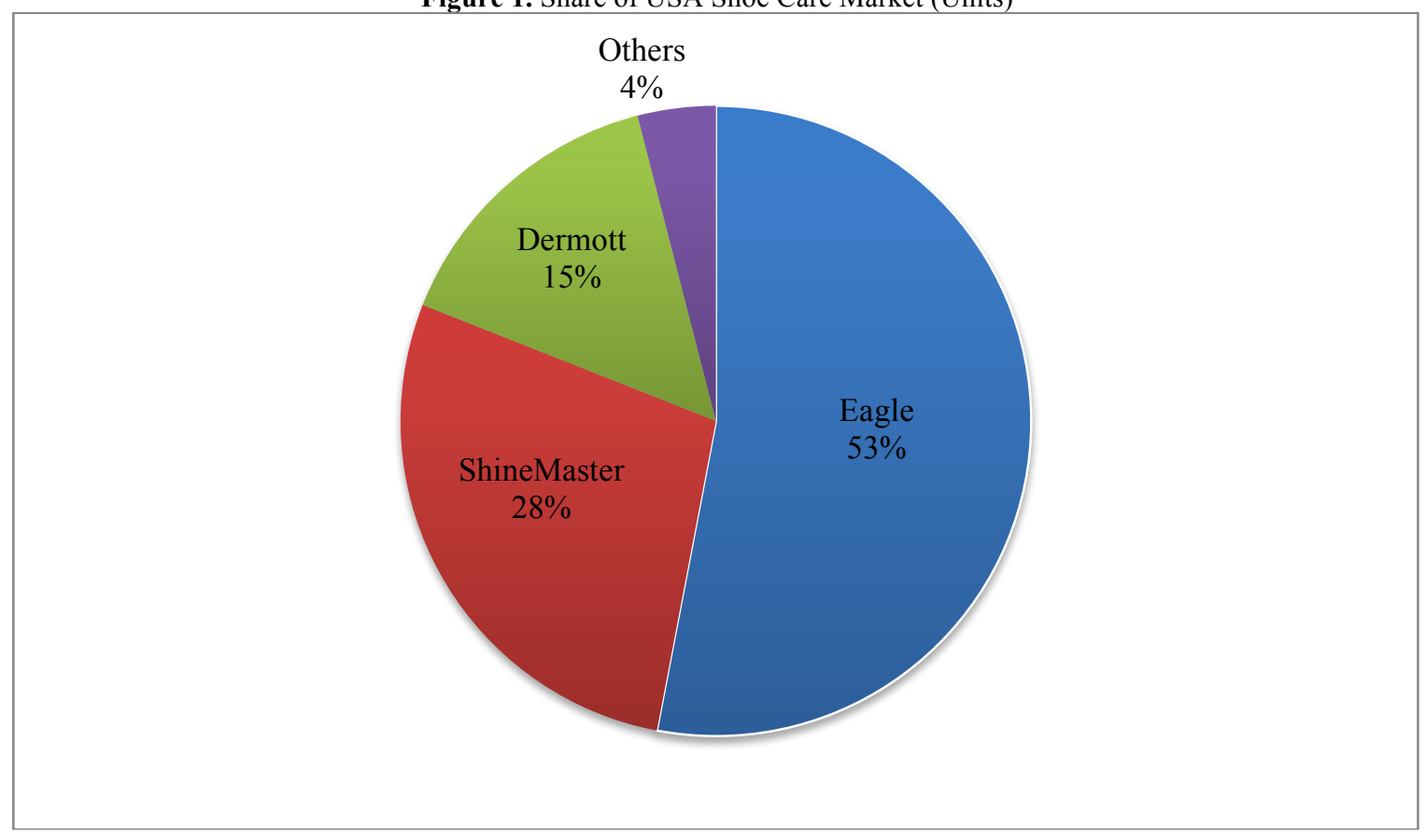

Figure 2. Share of USA Shoe Care Market (Dollars)

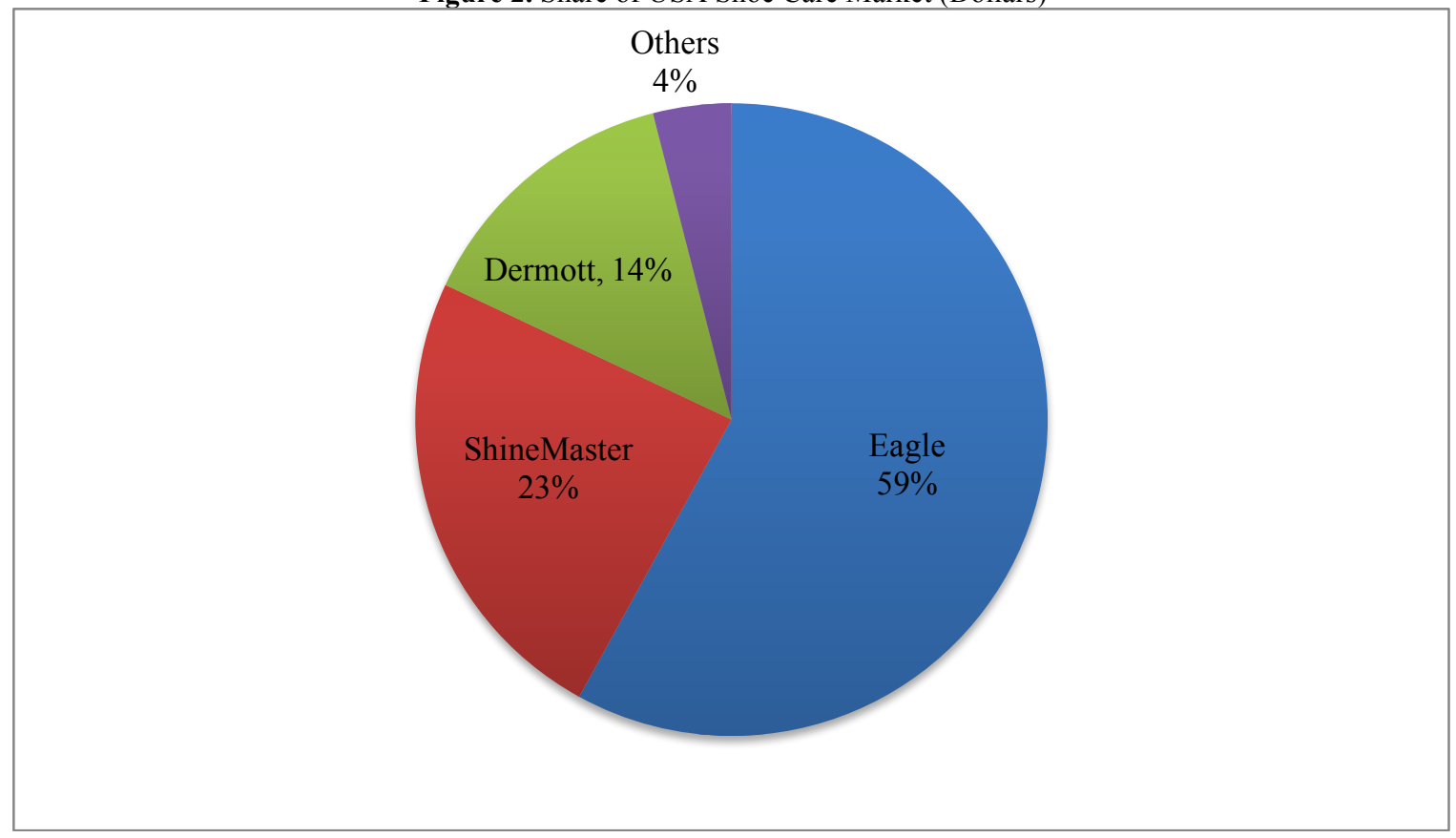


While the shoe care market is growing in parts of the world, such as China and India, it is gradually declining in developed markets like the USA. Figure 3 shows USA shoe care market unit trends from 2000-2015.

Figure 3. Share of USA Shoe Care Market (Dollars)

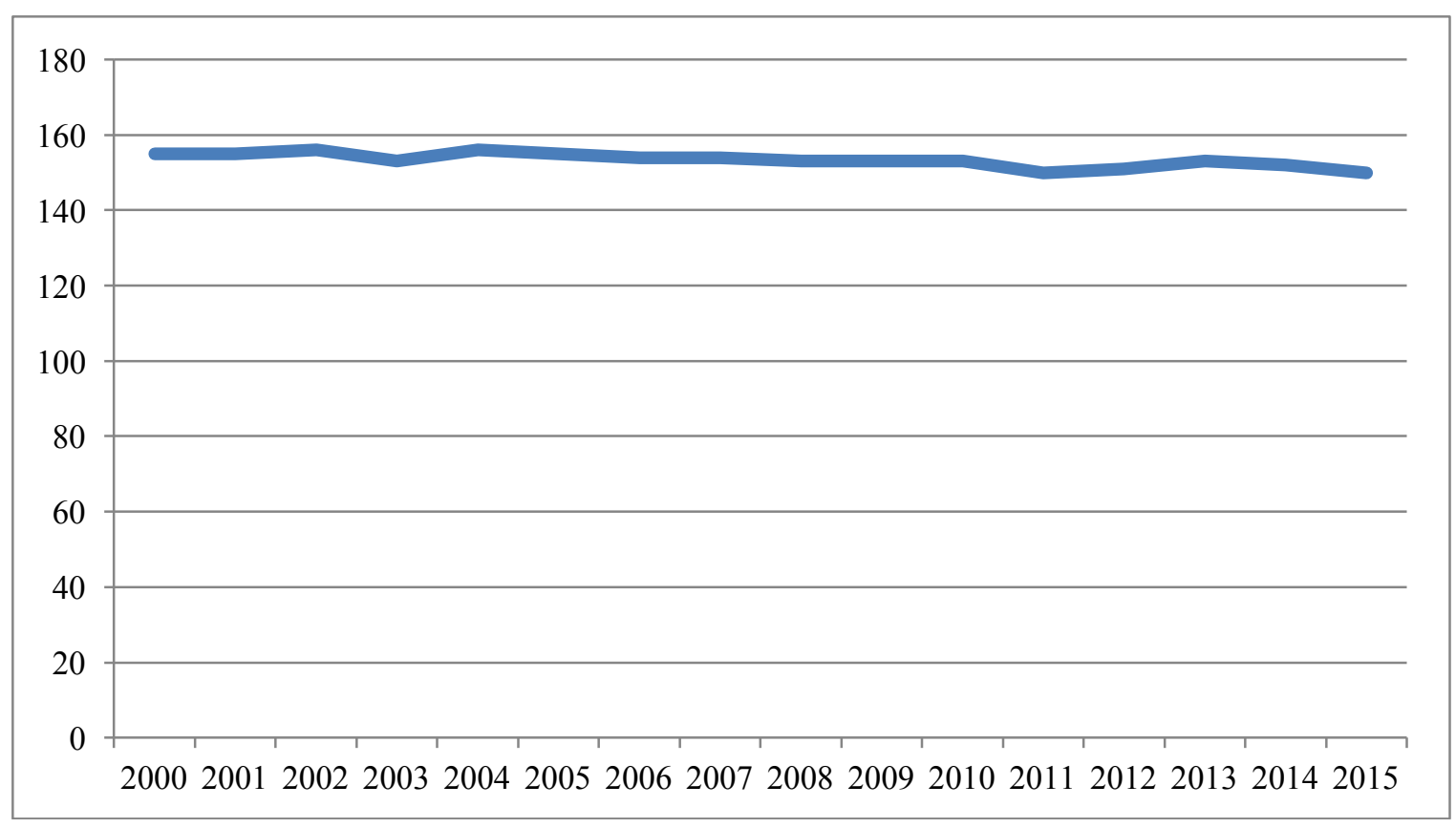

Eagle's market research budget is minimal but the brand subscribes to a service that provides household panel data, once every five years, showing the age and gender of adults in the USA who purchased a shoe care product in the past six months. Table 2 shows the 2015 results.

Table 2. Among Adults in USA, Percent Who Used Any Shoe Care Product in Past 6 Months

\begin{tabular}{c|c}
\hline Age: & $11 \%$ \\
\hline $18-39$ & $26 \%$ \\
\hline $40-59$ & $50 \%$ \\
\hline $60+$ & \\
\hline & \\
\hline Gender: & $35 \%$ \\
\hline Male & $14 \%$ \\
\hline Female & \\
\hline
\end{tabular}

To gain additional consumer insights, former Eagle Brand Manager Paul Hastings, commissioned research in 2012 to try to understand why people do and do not use shoe care products. Questionnaires were administered in seven shopping malls around the country, among a total of 210 heavy users, defined as adults using a shoe care product at least once a week, and 210 non- or light users, adults using less than once every three months. Respondents were asked why they did or didn't use shoe care products and they could choose from as many closed-ended alternatives (boxes) as they wanted. Tables 3 and 4 show the top responses from both segments surveyed. 
Table 3. Among Heavy Shoe Care Users in USA, Percent Citing Reason for Use (Multiple answers permitted)

\begin{tabular}{l|c}
\hline To produce a shine & $75 \%$ \\
\hline To cover marks or abrasions & $60 \%$ \\
\hline To protect against weather/elements & $40 \%$ \\
\hline To remove marks or stains & $15 \%$ \\
\hline To soften or nourish & $5 \%$ \\
\hline Other & $5 \%$ \\
\hline
\end{tabular}

Table 4. Among Non- or Light Shoe Care Users, Percent Citing Reason for Non-Use (Multiple answers permitted)

\begin{tabular}{l|c}
\hline Messy & $80 \%$ \\
\hline Inconvenient/time-consuming & $70 \%$ \\
\hline Don't wear shoes that need it & $50 \%$ \\
\hline Just buy a new pair & $40 \%$ \\
\hline Use soap and water & $35 \%$ \\
\hline Use colored marker & $15 \%$ \\
\hline Other & $3 \%$ \\
\hline Price & $2 \%$ \\
\hline
\end{tabular}

Within the company, people comment that the "new" (post-Desert Storm, 1991) military boots, made of lighter, non-leather materials that don't require polishing, have negatively impacted the business. In 1990, the military represented 10\% of Eagle shoe care sales, compared to 4\% in 2015.

In spite of an overall category decline, Eagle shoe care profits remain strong, with an average $39 \%$ gross profit margin per shoe care product. In fact, even though units have declined slightly, total Eagle profits continue to rise, fueled by recent price increases and a product mix shift toward newer, higher profit items. The most successful new product launch in the past ten years has been the Instant Shoe Shine Sponge, launched in 2007 and now the fifth highest-selling item in the Eagle line. Many other new products have been launched over the past two decades, but most cannibalized other Eagle items or could not generate enough sales to justify staying on the retail shelves. In 1990, the Eagle brand in the USA was comprised of 485 SKUs, compared to 184 in 2015.

In the past, when Eagle launched a new shoe care product, which was often, the sales force could easily convince retailers to stock it on their shelves. However, retailers are much more sophisticated today than they were ten or twenty years ago, due largely to the availability of data, such as product turn rate and profitability per SKU. Therefore, they are more selective in which products they put on the shelf and less patient in keeping slow-turning, low profit items. Their shelf space is like real estate. As explained by Eastern Division Sales Manager Jeff McAdams: "Retailers charge more for 'beachfront' locations, less for 'by-the-swamp'." Eagle products aren't bought or consumed as frequently as most grocery or drug store items, so they tend to be in the 'swamp' locations, by mops, fabric dyes, or other slower-turning items, in a less frequented aisle of the store. Retailers do, however, appreciate Eagle's strong brand equity and the high per-unit profit margins they provide, so they continue to allocate retail space rather generously.

All of EI's brands - Eagle, Penguin, Robin, and Cardinal - are sold in grocery, drug, and mass merchandise stores. Sales for these brands are managed by a sales vice president, two division managers (East and West), eight regional managers, and an outsourced network of sales representatives who handle household products for companies not large enough to have a dedicated internal sales force. Additionally, the Eagle brand is sold in specialty shoe and shoe repair stores, including both chains and a dwindling number of independent retailers, through a dedicated inhouse team of 45 sales people ( 39 men, 6 women.) About five percent of Robin insecticides and Cardinal industrial soaps is sold in large chain hardware and home improvement stores. These accounts are handled by the company's eight regional managers (all men), who admit they focus less on these accounts than on their grocery, drug and mass merchandise accounts.

The Eagle brand, with $\$ 113$ million in sales, is EI's cash cow, generating more sales and profits than the other brands combined and maintaining the highest profit margins. Insecticides is a growing market, especially the natural solutions segment, where the Robin brand is focused. Consequently, Robin dollar sales grew seven percent versus 
year-ago to $\$ 32$ million in 2015 , and unit market share grew to a record $12 \%$. The toilet bowl cleaner market is flat but the Penguin brand has been growing steadily by focusing on eco-friendly cleaning solutions. In 2015 , sales were $\$ 45$ million, up three percent versus year-ago. Cardinal industrial soaps occupy a small but steady market niche, with a loyal consumer following. Ninety-five percent of EI's advertising and promotion spending is allocated to the Robin and Penguin brands, primarily the natural/eco-friendly initiatives, with the remaining five percent allocated to Eagle.

All shoe care and toilet bowl products are produced at the Indiana headquarters, while the insecticides and soaps are made at a company-owned plant in South Carolina. Both plants are non-union. Shoe care is still the lead product at EI, but the other brands play a significant role. Table 5 shows sales of all EI brands.

Table 5. Eagle, Inc. Annual Revenue by Brand, 2015 (millions of dollars)

\begin{tabular}{l|l}
\hline & $\$ 113$ \\
\hline Eagle shoe care & $\$ 45$ \\
\hline Penguin toilet bowl cleaners & $\$ 2$ \\
\hline Robin insecticides & $\$ 6$ \\
\hline Cardinal industrial soaps & $\$ 196$ \\
\hline Total & 6 \\
\hline
\end{tabular}

\section{DILEMMA}

Newly hired Eagle Brand Manager, Abbie MacFeldon, stomps into her office and gives her potted ficus tree a swift kick with her freshly polished, pale ivory, leather dress shoe. "Drats! I thought I had a great idea for a new product." Her manager's words are still ringing in her ears: "We already tried that, and it failed." As Abbie sits down to rub her sore toes, she notices in frustration that the assaulted tree pot left a narrow dark mark along the side of her shoe. "See! We do need a product to fix this! But would I just be banging my head against the wall? Should I push my idea further, or should I move on and look for a different opportunity?" Like the kicked pot, Abbie wants to make her mark. Should she pursue her idea further, and if so, how?

\section{TALENT POOL}

Abbie MacFeldon - An energetic, ambitious 27-year old with an Ivy League MBA. After graduating, she worked in brand management for one of the world's largest consumer packaged goods companies. She struggled initially to establish herself, hesitant to ask others for help and reluctant to promote herself with upper management. She had reasoned: "I don't feel comfortable bragging about what I do. People will notice my good work." (They didn't.) However, with the help of a mentor, she turned things around and was on track for a promotion, just as family reasons prompted a move to Indiana. There, she landed a job with a smaller company that offered her a jump up to Brand Manager, on their biggest and most well-known brand, Eagle shoe care. Abbie has been determined to hit the ground running at her new company, working hard to learn the business and get to know the people. Three months in, she is adjusting to much smaller budgets and less staff support, but enjoying the freedom to wear many hats and to make decisions without layers of management approval.

Ivan Pierce - Group Marketing Manager, Shoe Care and Insecticides, and Abbie's direct manager. An outdoorsy Brit, aged 42, with a dry sense of humor (sometimes Abbie can't tell when he's joking), Ivan has worked around the globe for the company for decades. A chemist by background, he later switched to marketing, coupling strong product formulation knowledge with good sales and marketing instincts. He has a knack for anticipating things that could go wrong. Ivan is convinced by facts and numbers, wary of over-the-top new ideas, many of which he has seen fail over the years. He is honest and direct, and he supports his team privately and publically, regardless of which way the political winds blow.

Dave Rodriguez - Senior Research and Development (R\&D) Manager. A quiet, unassuming, hard worker, Dave has been with the company for 25 years. He proceeds at his own pace, no matter how "urgent" the request, often from a marketing person. He understands the importance of working methodically and avoiding mistakes. Dave wishes more people appreciated the important behind-the-scenes role that R\&D plays in developing and testing product formulations. He has a $\mathrm{PhD}$ in Organic Chemistry and takes great pride in having successfully filed over twenty shoe care patents. 
Dr. Ted Burkholder - Vice President, Engineering, Operations, and R\&D. No senior staff meeting would be complete without a raucous joke from Dr. Burkholder, punctuated with his hearty laugh. The doctor is widely respected in his field, and he travels extensively to conferences and global subsidiaries to share ideas. He typically has the last say on whether to build a new manufacturing line or reconfigure a current one, produce in-house or outsource, and pursue or discard a new product idea. A busy man, he does not like to be distracted by eager-beaver new hires. He has been with the company for 30 years.

Gary Clemson - Purchasing Manager. A 35-year old who loves to paint and play guitar, Gary wishes he had a job with more outlets for creativity, but he needs to pay the mortgage and feed six children at home. He often feels ignored by the marketing teams until they need him for last-minute emergencies. ("Help! Can we change to $100 \%$ compostable packaging by next month?") He gets stressed by constant changes in marketing plans, cost estimates, suppliers, and legal requirements.

Lakisha Dawne - Finance Assistant Manager. Hired two months ago, Lakisha, 24, works with three different marketing teams to provide sales and profit numbers. She is pragmatic and very detail oriented. She tries to keep a smile on her face, but feels overworked and somewhat nervous with so many people relying on her numbers. Lately, she has started to duck her head down when she sees a marketing person walk by her cubicle.

Jeff McAdams - Eastern Division Sales Manager, responsible for the entire eastern half of the US. Unlike his western counterpart, Jeff works out of the headquarters location, along with the President, the four Vice Presidents (Burkholder and the VPs of Finance, Sales \& Marketing, and Talent Resources) and most other managers, including all listed in the Talent Pool. Known for his sense of humor, he refuses to dive into business dealings until getting to know people a little, usually over a story or two...and often a beverage or two. Over the past ten years, he has earned the respect of buyers in grocery, drug, and mass merchandise retail establishments. He enjoys spending time with the marketing teams but wished they got "out in the field" more.

Bart Lee - Manufacturing manager. A mechanical engineer, Bart, 40, designs and modifies manufacturing equipment and procedures to produce the highest quality product at the lowest cost. One hundred percent of Eagle shoe care is produced in the USA, a point of pride for Bart and the entire manufacturing team. Eighty percent is produced at the Indiana headquarters; twenty percent is outsourced.

\section{THE MEETING - MONDAY 8:30 A.M.}

It's a grey March morning at EI's Springfield, Indiana headquarters. First-shift factory workers have been running production lines since 6:30 a.m. on the ground floor of the concrete-and-brick, two-story building, set on five acres on a relatively quiet road and ringed by trees. For non-factory personnel, the start time is 8:30 a.m. A few men and women in business casual attire are walking briskly across the parking lot toward the front entrance, travel coffee mugs in hand. Today marks Abbie's three-month anniversary with the company, and she is eager to boost sales for her brand, Eagle shoe care, and her reputation within the company.

\section{Abbie}

Standing in the doorway of her manager's office. Good morning, Ivan. How did the soccer game go last night?

Ivan

This old footballer taught the young 'uns a thing or two. M'knees feel it today, but I scored the first goal so it's all worth it. What's up?

\section{Abbie}

As long as it wasn't an own goal. Her eyes twinkle mischievously as Ivan shakes his head with a smile. I was wondering if you had some time this week to talk about an idea I have for the business.

\section{Ivan}

No time like the present. Come on in. 
Abbie

Thanks! As you know, I've been here three months now, and I've spent lots of time in those great informational interviews across the company that you helped set up for me - listening, learning, asking questions. Lots of questions.

\title{
Ivan
}

The first three months is the best time to ask questions. Especially the dumb ones. And it's so important to build connections early. The manufacturing and quality control folks told me they were pleased you took time to meet with them.

\begin{abstract}
Abbie
Good to hear. Thanks. At this point, I feel up to speed on the business - the financials, the products, the competitors, the consumer research we've done. I've kept a log of my observations, as you suggested, and there's one thing that really stands out to me. I've noticed that...

At this moment, Ivan's administrative assistant, Pat, bursts in. "Ivan, Dr. Burkholder is flying to Amsterdam today and he needs the latest volume projections for Project TopShelf."
\end{abstract}

Ivan

He doesn't leave 'til this evening. Tell him I'm in a meeting and we'll get it to him before lunch.

\begin{abstract}
Abbie
I ran the new numbers yesterday. We can look them over one more time and I'll get them to Ted.
\end{abstract}

Ivan

Great. Anyway, you were saying...

Abbie

Well, before I left BigBrands to come to Eagle, one of my girlfriends said, "Abbs, what I really wish your new company would make is a product to clean dark marks off light-colored shoes. I can't find anything to do this. It's a problem!"

Well, I kept my eyes out as I became familiar with our hundreds of SKUs, and I checked out the competitors' products, and I haven't come across any product that meets this need. So I'm thinking we should invent one.

Ivan

Love the way you're digging in, Abbie. Good stuff. We already tried that, though, and it failed.

\section{Abbie \\ Really?}

Ivan

Yes. We launched a clear liquid product to take dark marks off shoes or other leather or vinyl items. But we had to discontinue it after less than a year.

\author{
Abbie \\ Why? \\ Ivan \\ Sold slower than snowballs in the Arctic. Pity, that. Dave Rodriguez, down in R\&D - you've met him, right?
}

Abbie

A few times. I know he's played a key role in formulating a lot of our products. 


\section{Ivan}

Indeed. Well, Dave invented this one, too. He even got it patented. He wasn't too keen when we had to pull the plug on it. But retailers are sophisticated these days. They know when something isn't selling and they don't have much patience in keeping it on the shelf.

\section{Abbie}

Hmm. That's too bad.

\section{Ivan}

You could chat up Dave if you want to learn more. New products inject life into our business and we could bloody well use them. So keep coming up with creative ideas. Sooner or later, we'll hone in on a winner. Love the way you're thinking, MacFeldon!

Abbie almost thought Ivan was going to pat her on the head with an "Atta Girl;" she was relieved he went for an awkward fist bump instead. As she headed back to her office, something inside told her not to give up on this idea so easily. Then again, she didn't want to hit a brick wall with something that had already been tried and failed. She wanted to do something that would grow the business and also establish herself as a mover and shaker. Should she push this further or give up and move on to something else?

\section{REQUIREMENTS}

Answer the following questions, using data from the case and your own intuition.

1. Should Abbie pursue her new product idea further or let it rest?

a. Is there a consumer need for this product?

b. What would EI gain or lose by revisiting the idea of launching this product?

c. What would Abbie gain or lose?

d. Consider what is best both for the business and Abbie's career, then make and defend a choice based on what you know so far.

2. What additional information should Abbie gather to make the best decision?

3. If Abbie does pursue this idea, how can she gain internal company support?

a. From a people standpoint, whom should she leverage?

b. What approach should she take?

c. What obstacles might she face and how can she avoid or overcome these?

d. How might company culture play a role?

Educators: Teaching notes provided upon request. 


\section{New Product Launch For Eagle Brand: Marketing Management Case Study - B}

Educators: Hold this case until after Case A analysis and decisions. Credence should be given to alternatives proposed by students in Case A, even if they don't match Abbie's approach in Case B.

\section{INTRODUCTION}

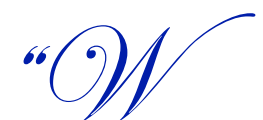

e already tried that and it failed." In spite of this reaction from her manager to a new line extension idea for her brand, Eagle shoe care Brand Manager Abbie MacFeldon has decided to push further. She wants to understand the what, how, and why of the previously failed launch, a product to remove dark marks from light-colored shoes, before throwing in the towel.

\section{DILEMMA}

Based on what Abbie learns in Case B about the previous new product launch that failed, has her line extension idea really already been tried, as her manager claims, or is her idea different? If she does pursue the idea, how can it be marketed externally? Specifically, how should the new product be targeted and positioned, and what should be the marketing plan? From a people standpoint, she knows she can't go this alone, but rather needs to form a team. But how can she motivate a team to take on a project that's not on anyone's official to do list or in the budget, and how should the team be managed?

\section{THE MORNING AFTER}

Yesterday, Abbie drove home feeling discouraged that her normally supportive manager was not excited about her idea for a line extension to the Eagle Shoe Care line. The shoe care category, in which Eagle holds the dominant share position, is declining. Young people and women are particularly underdeveloped as users, and the brand could really use a shot in the arm. Or the foot. Abbie's friends groan at her recent penchant for shoe care puns. Within the existing brand portfolio, Abbie noted that most of the SKUs (stock-keeping units, or products) add color to a shoe. Usually, this is a dark color, presumably to cover an area where the leather or other material has been abraded, and to restore color and shine. Her idea - actually it was suggested by one of her close girlfriends - is to remove color from a shoe, such as when a dark mark gets on a light-colored shoe. She cannot find anything within her brand's product line that performs this function, nor has she found a competitive offering.

Looking at consumer data, she recognizes that while 'removing marks or stains' from shoes is not a primary purchase driver, it is nonetheless cited as a reason-to-use by a significant $15 \%$ of heavy shoe care users. On top of this, the soap/water usage by a full $35 \%$ of light or non-users suggests that a specially designed shoe care product to clean/remove marks or stains is not available. After reviewing the data, Abbie wonders whether enough attention has been paid to women's shoe care needs, both because they are an underdeveloped market segment and because of the company's heritage. Eagle, Inc. (EI) seems to rely on traditional ways of achieving success and, much as Abbie gets along with everyone so far at the company, the employee composition is more male-dominated than she'd first realized. Abbie wants to shake things up a little, to make a difference. How frustrating that her first big idea has been rejected on the spot.

Today is a new day, however. In fact, it's barely 7 a.m., early even by Abbie's standards, as the determined brand manager scampers up the stairs from the factory floor level to her windowless, spartan, but spacious office on the second floor. Abbie has added a bit of character to the office with an inexpensive woven rug and a ficus tree, whose pot still bears the mark of yesterday's swift kick. "The data and my gut tell me that my idea is worth pursuing," she muses. "Plus, Ivan did not exactly say no. He left the door open to speak with Dave Rodriguez, in R\&D, to find out more. And he likes my initiative, so it's not like I need him to give me permission. I'm going to push to understand more." 
By 8:30 a.m., Abbie has pulled together the latest financials for her brand, a price comparison versus competition, and a brand awareness and image study that she had previously overlooked, shown in Tables 1, 2, and 3.

Table 1. Eagle Shoe Care Income Statement, 2015 (\$ millions)

\begin{tabular}{l|l|r}
\hline & & Percent of Net Sales \\
\hline Gross sales & $\$ 113.4$ & \\
\hline Returns, discounts, and allowances & $\$(4.4)$ & $100 \%$ \\
\hline Net sales & $\$ 109.0$ & $42 \%$ \\
\hline Cost of goods sold & $\$(45.8)$ & $58 \%$ \\
\hline Gross profit & $\$ 63.2$ & $2 \%$ \\
\hline Selling and marketing expenses* & $\$(2.2)$ & $8 \%$ \\
\hline Research and development expenses & $\$(8.7)$ & $11 \%$ \\
\hline Administrative expenses & $\$(12.0)$ & $37 \%$ \\
\hline Net income & $\$ 40.3$ & \\
\hline
\end{tabular}

*Consists mainly of sales compensation and commissions; includes advertising and promotion budget of $\$ 24,000$.

Table 2. Competitive Pricing Analysis Average Retail Price Per Unit (Across Channels), Using Comparably Sized Packages

\begin{tabular}{l|c|c|c}
\hline & Eagle & ShineMaster & Dermott \\
\hline Round tin wax polish & $\$ 1.79$ & $\$ 1.59$ & $\mathrm{n} / \mathrm{a}$ \\
\hline Bottle liquid polish & $\$ 1.59$ & $\$ .99$ & $\mathrm{n} / \mathrm{a}$ \\
\hline Instant shine sponge & $\$ 1.99$ & $\$ 1.79$ & $\mathrm{n} / \mathrm{a}$ \\
\hline Protector spray & $\$ 4.99$ & $\mathrm{n} / \mathrm{a}$ & $\$ 6.99$ \\
\hline Sneaker cleaner & $\$ 1.99$ & $\$ 1.79$ & $\mathrm{n} / \mathrm{a}$ \\
\hline Luxury cream polish & $\mathrm{n} / \mathrm{a}$ & $\mathrm{n} / \mathrm{a}$ & $\$ 5.99$ \\
\hline Leather softener & $\$ 2.99$ & $\$ 2.59$ & $\$ 4.99$ \\
\hline
\end{tabular}

Table 3. Eagle Brand Awareness and Image Study One-on-One Mall Intercept Interviews, January 24, 2012 Fort Wayne, Indiana

\begin{tabular}{|c|c|c|c|}
\hline & $\begin{array}{l}\text { Unaided awareness } \\
\text { (\% aware of Eagle) }\end{array}$ & $\begin{array}{c}\text { Aided awareness } \\
(\% \text { aware of Eagle })\end{array}$ & $\begin{array}{c}\text { Unaided image association } \\
\text { (top 3) }\end{array}$ \\
\hline $\begin{array}{l}\text { Age of Respondent } \\
\text { (40 people per group) }\end{array}$ & $\begin{array}{l}\text { "What shoe care brands have } \\
\text { you heard of?" }\end{array}$ & $\begin{array}{l}\text { "Have you ever heard of a } \\
\text { shoe care brand called } \\
\text { Eagle?" }\end{array}$ & $\begin{array}{l}\text { "Say the first words that } \\
\text { come to mind when you hear } \\
\text { 'Eagle shoe care'." }\end{array}$ \\
\hline $18-39$ & $7 \%$ & $47 \%$ & Bird, Grandpa, Old, \\
\hline $40-59$ & $35 \%$ & $90 \%$ & Messy, Polish, Trustworthy \\
\hline $60-79$ & $75 \%$ & $95 \%$ & $\begin{array}{l}\text { Shine, Trustworthy, Pride and } \\
\text { Quality (tied) }\end{array}$ \\
\hline \multicolumn{4}{|l|}{$\begin{array}{l}\text { Gender of Respondent ( } 59, \\
59, \text { and } 2 \text { people per group, } \\
\text { respectively) }\end{array}$} \\
\hline Male & $41 \%$ & $75 \%$ & Trustworthy, Pride, Old \\
\hline Female & $27 \%$ & $65 \%$ & Messy, Old, Grandpa \\
\hline Other/Prefer not to identify & $0 \%$ & $50 \%$ & Bird, Grandpa, Old \\
\hline
\end{tabular}

\title{
MEETING WITH DAVE RODRIGUEZ - TUESDAY, 9:00 A.M.
}

Abbie starts to pick up the phone, but opts instead to walk downstairs to the R\&D laboratory and surrounding offices, where she knocks Dave's door, which is open only a crack.

\author{
Abbie \\ Knock, knock! Hi, Dave! \\ Dave \\ Lowering his glasses as he looks up from a stack of paperwork. Mmmmm. 'Lo, Abbie.
}


Abbie

Ohhhh, looks like you're busy. Is there a better time?

\title{
Dave
}

I'm comparing material data safety sheet information for our aerosol sprays in 2016 and cross checking that against new government reporting regulations that came out last month. This is going to keep me busy most of the day.

\begin{abstract}
Abbie
Wow, sounds like a pain but thanks for keeping us on top of things. I was going to ask you about a great-sounding product that I hear you invented - for taking dark marks off shoes. But it can wai...

Dave

Oh, you mean this one?

He beckons Abbie into his office and swivels his chair around to grab a bottle on a shelf behind him.
\end{abstract}

\begin{abstract}
Abbie
She looks at the large, dusty bottle and reads the label aloud, noting the familiar Eagle logo, but with larger than usual, block, all-capitals lettering beneath it for the product name.

She reads aloud: Eagle Stain Remover. Cleans marks off leather, vinyl, and other surfaces.

Yes, that sounds like it! I told Ivan I thought we needed something to clean dark marks off shoes and he said you came up with something but we no longer sell it. What happened?

Dave

Yeah. It was a shame. This product works really well. Takes the marks right off. It dulls the finish a little bit but it's hard to notice. And you can easily fix that with a little clear polish on top. I, er we, even have a patent on the product.
\end{abstract}

\section{Abbie}

Sounds like such a good idea. Why isn't it still on the market?

Dave

Well, we got quick distribution in several hardware and home improvement stores, but then the product just sat on the shelf. Within six months, all the retailers dropped it.

\section{Abbie}

Did we ever get into grocery or drug stores?

\section{Dave}

Nope. Not sure if we tried. Here, you can have a better look at the bottle.

Abbie makes a quick sketch, shown in Figure 1. 
Figure 1. Abbie's quick sketch of Eagle Stain Remover bottle

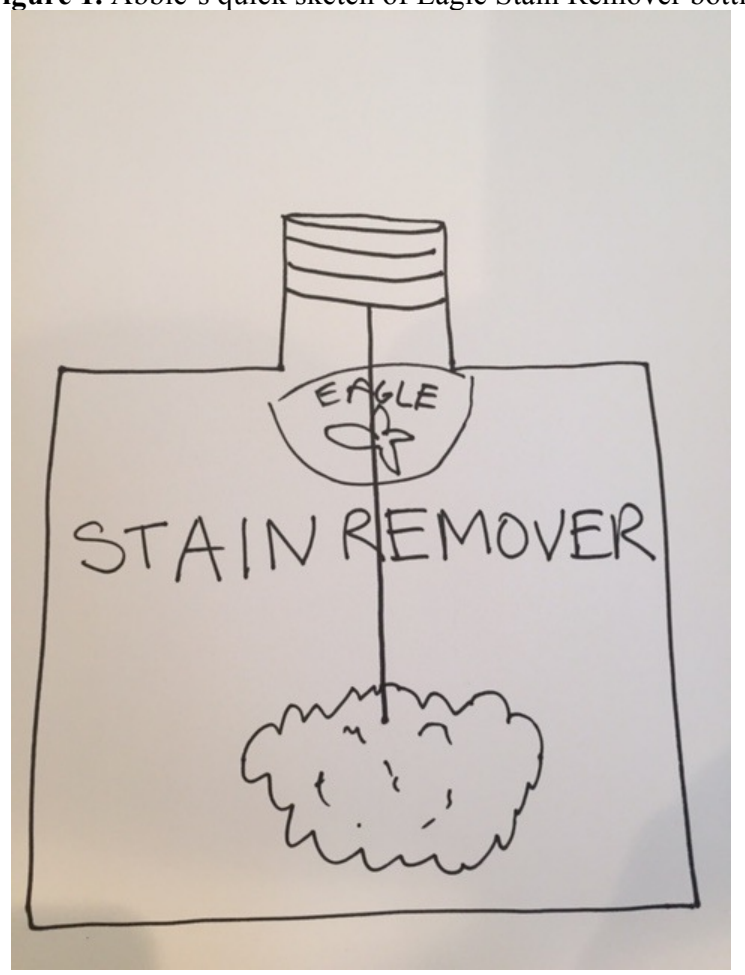

\title{
Abbie
}

It's nice the way it's clear and you can see that the liquid inside is clear. I wasn't picturing something quite so big.

\section{Dave}

It's ten inches high and seven inches wide.

\begin{abstract}
Abbie
She looks at the large block lettering on the label and then unscrews the cap. How does this wire pole and little mop work?

Dave

After you unthread, er unscrew, the cap, you pull the wire pole up through the bottle neck. This wrings out most of the liquid from the attached fibers that, you're right, look like a little mop. Then you rub this against your shoe...or purse or jacket .... or your sofa... or maybe even your floor - and it takes off the dark marks.
\end{abstract}

\section{Abbie}

I'm starting to wonder whether the product itself is good, but maybe it isn't packaged or targeted right.

\section{Dave}

The product itself is absolutely excellent. Nothing wrong there. We did lots of testing and it works great. I always figured it must have been marketed wrong.

\section{Abbie}

Well, I won't take any more of your time, Dave. Thanks for enlightening me.

\section{Dave}

Do you think we could give this thing another shot in some way? 
Abbie

That's what I want to think about. If we wanted to find another package for it, who would be the best person to talk with? I was thinking Gary Clemson?

Dave

Yup, Gary's your man for that. Let me know if you and he have any questions about product compatibility with the package.

Abbie

Will do. Thanks again, Dave.

\section{MEETING WITH GARY CLEMSON - TUESDAY, 9:45 A.M.}

Focused on her mission, Abbie ignores her usual mid-morning hunger pangs and race-walks across the concrete floor as smoothly as she can in a skirt and heels. No time to pop back upstairs for her energy bar. She reaches the corner of the building where Gary's office is located, away from the noise of the factory floor.

\section{Abbie}

Hi, Gary! I wanted to catch you before you get swamped with phone calls from packaging vendors. Is this a good time?

Gary

Well....

\section{Abbie}

Noticing a small painting tacked to the bulletin board behind his desk. Is that a watercolor of the covered bridge in Lahanska?

\section{Gary}

Yeah, it is. I drive over that bridge every morning to get to work. Last weekend it really stood out against the budding dogwoods. I wanted to capture that.

\section{Abbie}

Wait, you painted that! It's so pretty. The contrast between the brown tones in the bridge and the whites and greens of the trees is striking.

Gary

Thanks. That's kinda what I was going for.

Abbie

Well, it's not quite as much fun as painting, but I wonder if you could put your creative juices into helping us solve a problem.

Gary

What is it? Gary's desk phone rings and goes to voice mail.

\section{Abbie}

Well, I think we need a new product to clean dark marks off women's light-colored shoes and...

Gary

Just women?

\section{Abbie}

That's what I'm thinking. So, we have a formula. You might remember Eagle Stain Remover. 


\title{
Gary
}

Yup. Flopped. Fast.

\begin{abstract}
Abbie
True. But I am - we are - wondering whether maybe it would do a lot better if it were in a different package. Maybe something easier to handle, easier to control. Probably smaller. Maybe daintier, more feminine. Not exactly sure.

Gary

Hmmmm. He shuts his eyes and leans his head back. Just as Abbie is about to check his pulse, he sits upright, eyes opened.

Well, I have a few ideas. First off, what about a wipe? Could we put the formula into something like a disposable baby wipe? That would be quick and easy to control. We could package them in a box like wipes or tissues.
\end{abstract}

\begin{abstract}
Abbie
Cool idea. And people use wipes for all kinds of things. We use them in hot yoga to wipe down the mats.

Gary

Or, another idea - do you remember the original lip gloss packages? No, you're too young.

He pulls out a thin, cylindrical, clear plastic bottle, about three inches tall, including a one-inch black cap. The plastic is so clear that Abbie can see through the empty bottle. Gary unscrews the cap, revealing a circular, thin white fabric surface through which the product is applied .
\end{abstract}

\section{Abbie}

Playfully turns the bottle upside down and pretends to rub it on her lips. Good thing the bottle is empty!

\section{Gary}

Actually, you wouldn't have to worry. Just like lip gloss. Only a tiny bit would come out at a time, as you press on the surface.

\section{Abbie}

That sounds perfect. And it looks like a cosmetic product, very feminine. Almost elegant.

\section{Gary}

Or, another idea - we could source a shorter, narrower version of the original package. I'm sure I could find one with the same screw top, attached to a wire pole with the same fabric appendage.

\section{Abbie}

The little mop at the end? Wouldn't it still be a gloppy mess?

\section{Gary}

Not as bad as before because the whole thing would be maybe $25 \%$ smaller. And anyone who bought it before would recognize the package shape the second time around, so you might have better product awareness.

\footnotetext{
Abbie

Gary, these are great ideas. We might be onto something here! If I pull a new product launch team together with Dave, you, me, and probably Lakisha, to help us with the financials, would you be willing to be on it? You could tell the team about your packaging ideas and help us pick the best one.
}

\section{Gary}

Suppressing a smile, then creasing his brow. Well, yeah, I guess. How often would we meet? 
Abbie

We could have our first meeting tomorrow or the next day, to plot out a timetable, and then maybe once a week from there.

\title{
Gary
}

Once a week? Well, if we meet this Friday, I can come to the first one and then I'll try to make as many as I can. But I'm already working on the environmentally friendly repackaging project across the whole Eagle paste polish line, as you know. Every tin.

\begin{abstract}
Abbie
Yes, I do realize that. We will run our meetings efficiently and limit them to 30 minutes after the first one. Please say yes. This will be so exciting for the brand! And packaging will be key. We can't do it without your know-how. And creativity.

Gary

Okay, sure. As long as we meet Friday mornings. And why not invite Bart Lee, from manufacturing?

Abbie

You got it. Let's block out Friday mornings. I'll check with Dave, Lakisha, and Bart to pick the best time. I'll target 9 a.m. and get back to you later today. See you again on Friday, Gary. Thanks for your great ideas!

\section{TEAM MEETING - FRIDAY, 9:00 A.M.}

Assembled in a small conference room are Abbie, Dave (R\&D), Gary (Purchasing), Lakisha (Finance), and Bart (Manufacturing). Abbie watches as her cell phone changes from 8:59 to 9:00 a.m.

Abbie

Thank you all for taking time to meet today. Our two objectives for today's meeting are: (1) to understand a new Eagle product idea - what it does, who might want it, and how it might be changed versus when it was launched before, and (2) to decide as a team whether to launch this product in a new way. Today, we will go for an hour, ending at 10:00 sharp, and after this we can limit our weekly team meetings to half an hour.
\end{abstract}

\section{Lakisha}

Hang on. Did you say this was already launched before?

Abbie

Yes, and frankly, it flopped, but we have ideas to make it new and different.

\section{Lakisha}

So, are we still talking about using the Eagle brand? If you really want to be new and different, especially after a flop (she pauses for emphasis), would you invent a new brand name? To be honest, Eagle didn't mean much to me before I worked here.

\footnotetext{
Abbie

Good question, Lakisha, and yes, we were thinking of this as a line extension under the Eagle brand. But, if you're okay, let's hold that thought for later and focus on our two primary objectives for today. Lakisha nods assent.

Dave, since you are the brains behind this product, can you kick things off by describing the product and how it works?

Dave

Sure, I'd be happy to. Dave passes the original bottle around the table proceeds to explain how the product works and what materials it can be used on.
} 
Abbie

Thanks, Dave. As you might be sensing, we have a great product here, but maybe not the right marketing behind it. For one thing, the packaging should probably be changed. Gary came up with some great ideas to repackage. Gary, can you...

Lakisha

Can I just ask? Where are you getting the money for this? I don't see it budgeted anywhere.

\begin{abstract}
Abbie
You're right Lakisha. There's no budget because we just came up with the idea this week. Isn't there a general fund for new product development we could tap into?

\section{Lakisha}

Rolling her eyes with a chuckle. I've only been here two months, but that's long enough to know there's no extra money hanging around anywhere. Just a little development money here or there for high-priority initiatives. Any marketing for this would have to come from within your existing Eagle brand marketing budget. Any packaging redesign or product reformulation would have to come from those departments' existing budgets.
\end{abstract}

\begin{abstract}
Abbie
All of which are pretty tight as it is. Hmmm. Okay, we'll have to wrestle with that one. Gary, can you share your creative packaging ideas with us?
\end{abstract}

\title{
Gary
}

If we want to keep things as close to the original launch as possible, I did find a downsized version of the initial jumbo-sized package, with the wire and "little mop," as Abbie calls it. He shows an image on his cell phone to the group.

\section{Dave}

That would work from an R\&D end. We wouldn't need to do any additional product compatibility as long the bottle materials are exactly the same.

\section{Gary}

They are. Same manufacturer.

\section{Dave}

That's good. For performance, we'd need to run a quick test to show that the little mop squeezes up through the bottle neck properly. I imagine there would still be dripping but hopefully no worse than the first time.

\section{Bart}

It probably wouldn't be too hard to do a change-part on the production line we used before to accommodate this smaller bottle.

\section{Gary}

Another idea would be a wipe. Like a baby wipe or cleaning wipe. We could package disposable wipes in a plastic tub or box, like people are used to.

\section{Dave}

Hang on. I don't know if this product formula would work in a wipe. For one thing, your fingers shouldn't touch the chemicals directly - at least not in large doses. Also, the product might react negatively with the wipe.

\section{Bart}

We would have to outsource this one. We don't have the capability to make this. 
Abbie

Well, we do outsource other items. And if sales took off, might it justify building a line in-house?

\title{
Bart
}

Maybe. That's happened before.

\author{
Abbie \\ But back to putting the formula into a wipe. Can we do this, Dave? \\ Dave \\ We'd need a lot of testing. My gut says no. But we could easily replicate the same formula that the leading \\ household cleaning wipe uses.
}

\begin{abstract}
Abbie
You mean like the ones we use to wipe down gym equipment or kitchen counters?

Dave

Exactly. The performance isn't as strong as our Stain Remover product but could we just label them as shoe care "cleaning wipes"? They'd be no better or worse than the cleaning wipes on the market now. Of course, we would have to limit what we claim as far as performance.
\end{abstract}

\begin{abstract}
Abbie
What could we claim? Would the product really remove dark marks?

Dave

We could run some simple tests. I can't answer that now. Doubtful it would be as efficacious - er, effective - as the liquid formula I developed.
\end{abstract}

\begin{abstract}
Abbie
Okay, Gary, we have fifteen minutes left. Tell us your third idea. The lip gloss one.
\end{abstract}

\section{Gary}

After our meeting Wednesday, I ordered samples from the vendor. He passes them around and explains the concept, as he had previously to Abbie.

Into the room strides Jeff McAdams, ducking by habit under the door frame.

\section{Jeff}

Hey, guys! You all look so serious. Don't take the Pacers' loss so hard, haha. We have the room at 10 and I just thought... He picks up a lip gloss bottle. Hey, what's this? Please don't tell me you're putting shoe polish in here. These little babies would roll right off the shelf. And they're glass! Can you imagine?

\section{Abbie}

To Gary. I thought you said they were plastic.

\section{Gary}

They come in both. Plastic is less expensive but I thought glass looked more elegant so I ordered that one.

\section{Dave}

And we know glass is compatible with the product. For plastic, we'd have to run new tests. Either way, though, would it look serious and trustworthy enough to fit in our Eagle line-up? 
Abbie

Well, it's 9:55. I realize we need more information. But, picture repositioning this product for women, as a way to remove dark marks from light-colored shoes, and remarketing the product - new package, new price, maybe new distribution channels, new promotion. Let's vote. Put up your hand if you think we should pursue this new product launch further.

Abbie and Gary immediately thrust hands high, followed a second later by a bent-armed Dave. Bart shrugs his shoulders in an indifferent way, while Lakisha shakes her head as though this is too much to process at the moment.

\section{Jeff}

New product, you say? Heck, yeah. We're the leaders in the category. We need to show the retailers we are constantly innovating. And think of all the new sales that come in when we fill the inventory pipeline with new stuff.

Still standing, he raises his hand to add a yes vote and nearly cracks the fluorescent light above. Ouch!

Other employees start to enter the room.

\section{Abbie}

Yikes, we need to clear out. Well, I think we have enough consensus here to move forward. Bart and Lakisha, I know you have very valid questions and we'll try to address those for you. On Monday, I'm going to recommend to Ivan that we move forward with a launch. I will summarize our meeting and circulate next steps later today. If you have questions, please get in touch. Thank you all for your time! See you next Friday 9-9:30 for our first official Project Eraser team meeting!

\section{HERE COMES TROUBLE -- FRIDAY 3:30 P.M.}

Dr. Ted Burkholder tosses his suitcase by the massive oak desk in his tall-windowed corner office and storms up the stairs to Ivan's office. Ivan, about to make a phone call, sets down the phone when he sees his colleague's reddened face and fiery eyes.

\section{Dr. Burkholder}

What the $* \& \% \$$ is Project Eraser?

Ivan

Come again?

\section{Dr. Burkholder}

I call from my car on the way back from the airport for some technical specs on the tin redesign. And I'm told that Rodriguez is busy testing something for "Project Eraser" - a new product coming from mar-ket-ing. The last word is pronounced as though it is a disease.

Something about women's shoes. Your group. What can you tell me about this?

\section{Ivan}

Mmmmmm. Tell you what, Ted. I don't have all the details at my fingertips, but let me convene with Abbie and can we circle back with you in about an hour? We will be in a better position to brief you fully. You look like you could use a short rest, anyway.

\section{Dr. Burkholder}

Letting out a sigh. Okay, sure. I have to sort through some emails right now anyway. But I need some answers pretty quick. 
Ivan

Once Dr. Burkholder is out of earshot, he calls out loudly toward the office next door.

Abbie....!!!!

\section{REQUIREMENTS}

Answer the following questions using data from the case and your own intuition:

1. What did Abbie do well championing this new product idea within the company? What did she do poorly?

2. Imagine the interaction between Ivan and Abbie at the end of the case. What happens? (Educators: consider a role play.) After the imagined meeting, what should Abbie do from here?

3. Assuming the Project Eraser launch moves forward, create a marketing plan overview that includes:

a. Unique Selling Proposition

i. In one phrase or sentence: why will someone buy this/how is it better than the competition?

b. Target Audience

i. In one sentence: who will buy it? Capture key demographic, geographic, and/or psychographic components.

c. Name for the new product

i. Brand: a line extension under the Eagle brand, or a new brand?

ii. Sub-brand: Stain Remover (again), or something different?

d. The 4 Ps of the Marketing Plan

i. Product: choose from among the three packaging options presented by Gary.

1. If you pick the wipe: a) use existing technology that performs like existing household cleaning wipes or b) develop special shoe care formula to work as well as the bottled version?

2. If you pick the lip gloss package: plastic or glass?

3. If you pick the downscaled version of previously launched product, provide dimensions.

ii. Price: premium, parity, or discount versus competition? Versus other Eagle SKUs?

iii. Place: grocery, drug, mass, specialty, hardware, home improvement, and/or other?

iv. Promotion: how will you build consumer awareness and trial - within a small promotion budget?

Educators: Teaching notes available upon request.

\section{AUTHOR BIOGRAPHY}

Amy MacMillan is the L. Lee Stryker Assistant Professor of Business Management at Kalamazoo College. She spent fifteen years in marketing management with Procter \& Gamble and Sara Lee, in the US and Europe, followed by ten years teaching marketing, advertising, management, and strategy. She has published papers about online purchase decision-making and collaborative teaching evaluations, one of which won the Marketing Managers Association Best Conference Refereed Paper Award in Fall 2014. Ms. MacMillan holds a BA from Colgate University and an MBA from Harvard Business School. E-mail: amy.macmillan@kzoo.edu

\section{SUGGESTED LITERATURE}

\section{Leadership, Team Building, and Organizational Culture}

Cameron, K. \& Quinn, R. (1999). Diagnosing and changing organizational culture: Based on the competing values framework. Reading, MA: Addison-Wesley.

George, B. (2007). True north: Discover your authentic leadership. San Francisco, CA: Jossey-Bass. 
Liswood, L. (2010). The loudest duck: Moving beyond diversity while embracing differences to achieve success at work. Hoboken, NJ: John Wiley \& Sons.

Northouse, P. (2016). Leadership: Theory and practice $\left(7^{\text {th }}\right.$ ed.). Thousand Oaks, CA: Sage Publications.

Sandberg, S. (2013). Lean in: Women, work, and the will to lead. New York, NY: Alfred A. Knopf.

Stewart, G., Manz, C., \& Sims, H. (1999). Team work and group dynamics. New York, NY: John Wiley \& Sons.

\section{Marketing Plans, New Product Launches and Positioning, and Winning Consumers}

Brennan, Bridget (2009). Why she buys. New York, NY: Crown Business.

Cialdini, R. (2007). Influence: The psychology of persuasion. New York, NY: HarperCollins.

Hall, J. \& Schneider, J. (2011). Why most product launches fail. Harvard Business Review. Retrieved from https://hbr.org/2011/04/why-most-product-launches-fail.

Kotler, P. \& Armstrong, G. (2016). Principles of marketing $\left(16^{\text {th }}\right.$ ed.). Upper Saddle River, NJ: Pearson Prentice Hall.

Mangram, M. (2012). The globalization of Tesla Motors: A strategic marketing plan analysis. Journal of Strategic Marketing, 20.4, 289.

Omansky, M. (2012). Positioning product for success. International Journal of Management and Administrative Sciences, 1.5, 20-22.

Ries, A. \& Trout, J. (2001). Positioning: The battle for your mind. New York, NY: McGraw Hill.

Wood, M. (2014). Marketing plan handbook (5 ${ }^{\text {th }}$ ed.). Harlow, England: Pearson.

Quinlan, M. (2003). Just ask a woman: Cracking the code of what women want and how they buy. Hoboken, NJ: John Wiley \& Sons. 


\section{NOTES}

